\title{
Allergen Levels in the Hair of Different Cattle Breeds
}

\author{
Eva Zahradnik Ingrid Sander Thomas Brüning Monika Raulf \\ Institute for Prevention and Occupational Medicine of the German Social Accident Insurance (IPA), Institute of the \\ Ruhr-Universität Bochum, Bochum, Germany
}

\section{Key Words}

Bovine allergens $\cdot$ Bos $\mathrm{d} 2 \cdot$ Cattle hair $\cdot$ Cattle breeds . Occupational allergen

\begin{abstract}
Background: Cattle are well-known sources of respiratory allergens in agricultural environments. Breed-specific differences in Bos $\mathrm{d} 2$ (a major bovine allergen) levels in cattle hair have been previously suggested but not fully characterized. Therefore, the aim of the current study was to determine whether hair from common cattle breeds differs in protein and allergen content. Methods: In total, 80 hair samples from 16 different cattle breeds were analyzed. The protein concentration was determined using the Bradford assay. The allergen content was measured using a sandwich ELISA based on polyclonal antibodies against a bovine hair protein extract and a commercial immunoassay based on monoclonal antibodies against Bos d 2. Results are given in micrograms per gram of hair. Statistical analysis was performed using the Kruskal-Wallis test and Spearman's rank correlation. Results: A wide variability in all 3 tested parameters was observed between the individual samples. The protein content differed by about 35 -fold $(0.3-12 \mathrm{mg} / \mathrm{g})$, the bovine hair allergen content differed by about 500-fold (37-18,553 $\mu \mathrm{g} / \mathrm{g}$ ), and the Bos $\mathrm{d} 2$ content differed by about 1,200-fold $(5-6,323 \mu \mathrm{g} / \mathrm{g})$. Protein, bovine hair allergen, and Bod d 2 values correlated strongly and significantly with one another. The median Bos d 2/bovine hair allergen ratio was 0.28 . No significant differences were found between the most
\end{abstract}

common breeds in Germany (Simmental, Holstein, and Braunvieh) and a group of rare breeds or between female and male animals. Conclusions: The results confirm a high variability in allergen levels between individual animals but also indicate that allergen production is related neither to the breed nor to gender.

C 2015 S. Karger AG, Basel

\section{Introduction}

Cattle allergy is almost exclusively associated with occupational exposure and occurs primarily in cattle farmers, veterinarians, claw trimmers, and workers involved in artificial insemination. In Germany, about $9 \%$ of all cases of suspected occupational airway diseases among farmers reported between 1990 and 2002 were due to cattle allergies [1]. The proportion of patients symptomatic to cattle varied strongly across different regions of Germany, from $4 \%$ in North Rhine-Westphalia and Hesse to $19 \%$ in Lower Bavaria and the Upper Palatinate. No explanation for these considerable regional discrepancies could be found; however, region-specific techniques in cattle husbandry, such as the type of housing or breed selection, may have been responsible.

The main sources of bovine respiratory allergens are cow hair and dander. Using crossed immunoelectrophoresis, early investigations of bovine materials found 17 different antigenic components, 4 major allergens, and 6 minor allergens [2,3]. Currently, only some of these proteins are 
characterized and listed in the official World Health Organization/International Union of Immunological Societies (WHO/IUIS) allergen database (www.allergen.org). The lipocalin Bos $\mathrm{d} 2(20 \mathrm{kDa})$ is the major respiratory allergen [4-6]. Immunoblotting analysis has indicated that more than $90 \%$ of patients suffering from cattle-associated asthma have IgE antibodies against natural Bos d 2 [7]. Another potential major allergen present in cow dander, which is not yet in the official database, is Bos d $23 \mathrm{k}-\mathrm{a}$ $23-\mathrm{kDa}$ protein related to a family of odorant-binding proteins [8]. One of the minor allergens is the calcium-binding protein Bos d $3(11 \mathrm{kDa})$. The frequency of IgE reactivity to recombinant Bos $\mathrm{d} 3$ is about $40 \%$ in cattle-allergic subjects [9]. Further minor allergens present in cow hair and dander extracts are serum albumin Bos d $6(67 \mathrm{kDa})$ and IgG Bos d 7 (160 kDa) [3]. Other identified allergens of bovine origin (Bos d 4, 5 and 9 -12) include milk proteins, which play an important role in food allergy [10].

Only few studies have been conducted to investigate the qualitative and quantitative differences in allergen production between different cattle breeds. SDS-PAGE analysis of cow hair extracts has shown nearly identical protein patterns with a dominant band at $20 \mathrm{kDa}$ without any striking breed- or gender-specific differences. Some variations have appeared in the intensities of single bands of protein profiles [11]. Using immunoelectrophoresis methods, only minor differences in allergen composition have been identified upon analysis of material from 4 different cattle breeds [2]. Quantitatively, Heutelbeck et al. [12] found a high variability in Bos d 2 content between individual cattle and suggested that certain breeds, e.g. Simmental, have higher Bos d 2 quantities in their hair compared to others. The authors discussed that the higher proportion of cattle-allergic farmers in Southern Germany (double the German average) could be associated with the higher Bos $\mathrm{d} 2$ content found in Simmental cattle, which is the predominant breed found in this region. However, the sample size of this study was relatively small, with only 18 hair samples (1-4 samples per breed).

The aim of this study was the quantitative analysis of hair samples obtained from cattle of different breeds. Hair extracts were compared in relation to protein, bovine hair allergen, and Bos $\mathrm{d} 2$ content.

\section{Materials and Methods}

\section{Sample Collection}

In total, 80 hair samples were collected from 16 different cattle breeds used for dairy and/or beef production [Simmental, $\mathrm{n}=31$; Holstein, $\mathrm{n}=16$; Braunvieh (brown cattle), $\mathrm{n}=12$; Pinzgauer, $\mathrm{n}=$
4; Tyrolese Grey, $\mathrm{n}=3$; Charolais, $\mathrm{n}=2$; Limousin, $\mathrm{n}=2$; Tux, $\mathrm{n}=$ 2; Angus, $\mathrm{n}=1$; Montbéliard, $\mathrm{n}=1$; Belgian White Blue, $\mathrm{n}=1$; Pustertaler Sprinzen, $\mathrm{n}=1$; Angler, $\mathrm{n}=1$; Murboden, $\mathrm{n}=1$; Murnau-Werdenfels, $\mathrm{n}=1$, and Hungarian Grey, $\mathrm{n}=1]$. Each sample was collected from a different cattle farm. Fifty-seven samples were obtained from female animals and 15 samples were obtained from male animals. For 8 samples, the sex of the animal was not documented. Hair was collected from adult animals (2-4 years old) by cutting or shaving as close to the skin as possible. Hair was sampled from body parts without visible contaminations, mostly from the dorsum or flanks of the animal.

\section{Extraction}

Extractions were performed by rotating $1 \mathrm{~g}$ of hair in $10 \mathrm{ml}$ of phosphate-buffered saline (PBS; pH 7.4) plus $0.05 \%$ Tween 20 (PBST) for $1 \mathrm{~h}$ at room temperature. The extracts were passed through folded filters (Whatman, Dassel, Germany) and centrifuged for $25 \mathrm{~min}$ at 20,000 $\mathrm{g}$. The supernatant was stored in aliquots at $-80^{\circ} \mathrm{C}$ until analysis. The protein concentration was determined using the Bradford assay (Bio-Rad Protein Assay; Munich, Germany) with bovine serum albumin as a standard.

\section{Bovine Hair Allergen Assay}

Bovine hair allergen concentrations were determined via a sandwich ELISA as described by Zahradnik et al. [11]. The assay was developed using affinity-purified polyclonal antibodies against the total soluble antigen spectrum extracted from bovine hair. The bovine hair extract was previously examined for the presence of allergens using an IgE immunoblot with sera from several cow dander-sensitized patients, which recognized almost the entire protein pattern [11].

Briefly, Nunc Maxisorp microtiter plates (Thermo Fisher Scientific, Roskilde, Denmark) were coated overnight at $4{ }^{\circ} \mathrm{C}$ with anticow hair polyclonal antibodies in $100 \mathrm{mM}$ carbonate buffer ( $\mathrm{pH} 9.6$; $1 \mu \mathrm{g} / \mathrm{ml}$ ) and blocked with $1 \%$ gelatin in PBST. Afterwards, the plates were incubated with standards, assay controls and samples diluted in PBST. A commercial cow dander extract (Allergon, Ångelholm, Sweden) was used as a standard, with concentrations ranging from 10 to $0.08 \mathrm{ng} / \mathrm{ml}$. Cow shed settled dust extract was used as a positive control and wheat flour extract was used as a negative control. Biotinylated anti-cow hair polyclonal antibody was added at $0.1 \mu \mathrm{g} / \mathrm{ml}$ PBST, followed by incubation with streptavidin horseradish peroxidase diluted 1:20,000 in PBST (PolyHRP80-SA; Fitzgerald, Concord, Mass., USA). All incubations were carried out for $1 \mathrm{~h}$ at $22^{\circ} \mathrm{C}$ with intermediate washes with PBST between successive steps. Finally, the plates were developed with ABTS tablets [2, 2'-azino-bis(3-ethylbenzothiazoline-6-sulfonic acid) diammonium salt; Sigma-Aldrich, Steinheim, Germany] diluted in $50 \mathrm{mM}$ phosphate-citrate buffer ( $\mathrm{pH} 4.2$ ) with $0.015 \%$ hydrogen peroxide. The reaction was stopped with $0.32 \%$ sodium fluoride, and the optical density (OD) was read at $414 \mathrm{~nm}$. Sample concentrations were interpolated from a 4-parameter standard curve using Softmax Pro 5.4.1 (Molecular Devices, Sunnyvale, Calif., USA). The lower limit of detection (LOD) was the concentration corresponding to the minimal value of the 4-parameter curve fit function plus the 6-fold standard deviation of the zero standard $\left(\mathrm{OD}_{414}=\right.$ 'parameter $\left.\mathrm{A}^{\prime}+0.15\right)$. The average LOD of the assay was $0.1 \mathrm{ng} / \mathrm{ml}$. Every hair sample was tested using 3 serial dilutions, and the mean of 3 corresponding concentrations was used as the final result. Results are given in micrograms per gram of hair.
10

Int Arch Allergy Immunol 2015;167:9-15 DOI: $10.1159 / 000431227$
Zahradnik/Sander/Brüning/Raulf 
Table 1. Protein, bovine hair allergen, and Bos d 2 levels in cattle hair

\begin{tabular}{|c|c|c|c|c|c|c|c|c|c|c|c|c|c|}
\hline & $\begin{array}{l}\text { Samples, } \\
\mathrm{n}\end{array}$ & GM & median & range & GM & median & range & GM & median & range & GM & median & range \\
\hline \multicolumn{14}{|l|}{ Breed } \\
\hline Simmental & 31 & 2,946 & 3,087 & $345-11,966$ & 2,424 & 2,747 & $37-16,790$ & 567 & 770 & $5.3-3,406$ & 0,23 & 0.26 & $0.06-0.43$ \\
\hline Holstein & 16 & 3,137 & 3,253 & $1,304-10,177$ & 2,666 & 3,241 & $553-7,528$ & 796 & 842 & $206-2,292$ & 0.30 & 0.31 & $0.18-0.54$ \\
\hline Pinzgau & 4 & 3,481 & 3,457 & $2,962-4,152$ & 2,388 & 2,470 & $1,640-3,332$ & 809 & 794 & $588-1,212$ & 0.34 & 0.32 & $0.22-0.59$ \\
\hline Tyrolean Grey & 3 & 3,569 & 3,486 & $2,930-4,451$ & 2,730 & 2,594 & $1,917-4,093$ & 859 & 816 & $668-1,165$ & 0.31 & 0.31 & $0.29-0.35$ \\
\hline Limousin & 2 & 1,897 & 1,948 & $1,504-2,392$ & 689 & 1,076 & $249-1,904$ & 235 & 366 & $86-645$ & 0.34 & 0.34 & $0.34-0.34$ \\
\hline Charolais & 2 & 2,024 & 2,261 & $1,253-3,268$ & 1,221 & 1,527 & $610-2,443$ & 314 & 482 & $117-846$ & 0.26 & 0.27 & $0.19-0.35$ \\
\hline Tux-Zillertal & 2 & 4,328 & 4,796 & $2,731-6,860$ & 3,532 & 3,996 & $2,126-5,866$ & 845 & 959 & $506-1,412$ & 0.24 & 0.24 & $0.24-0.24$ \\
\hline Angus & 1 & & 881 & & & 259 & & & 56 & & & 0.22 & \\
\hline Murboden & 1 & & 3,027 & & & 3,965 & & & 1,155 & & & 0.29 & \\
\hline \multicolumn{14}{|l|}{ Murnau- } \\
\hline $\begin{array}{l}\text { Werdenfels } \\
\text { Pustentaler }\end{array}$ & 1 & & 1,129 & & & 652 & & & 112 & & & 0.17 & \\
\hline Spinzen & 1 & & 3,283 & & & 1,459 & & & 477 & & & 0.33 & \\
\hline Hungarian Grey & 1 & & 1,641 & & & 493 & & & 149 & & & 0.30 & \\
\hline \multicolumn{14}{|l|}{ Sex } \\
\hline Female & 57 & 2,900 & 2,962 & $345-11,966$ & 2,265 & 2,747 & $37-14,032$ & 572 & 680 & $5.3-3,406$ & 0.25 & 0.27 & $0.06-0.54$ \\
\hline Male & 15 & 2,495 & 2,431 & $656-8,857$ & 1,632 & 1,640 & $249-18,553$ & 505 & 604 & $86-6,323$ & 0.31 & 0.34 & $0.06-0.59$ \\
\hline
\end{tabular}

$\mathrm{GM}=$ Geometric mean.

Bos 2 Assay

Bos $\mathrm{d} 2$ concentrations were quantified using an ELISA kit with monoclonal antibodies and recombinant Bos $\mathrm{d} 2$ as a calibration standard (Indoor Biotechnologies Inc., Charlottesville, Va., USA). The capture antibody 3D4 and the biotinylated detection antibody $\mathrm{mAb} 1$ were used at 1:1,250 dilutions. The standard was used in a concentration range of 5-0.02 $\mathrm{ng} / \mathrm{ml}$. All other reagents, buffers, incubation steps, and calculations were used and performed according to the protocol of bovine hair sandwich ELISA as described above. The average LOD ('parameter A' + 0.05) of the Bos $\mathrm{d} 2$ assay was $0.03 \mathrm{ng} / \mathrm{ml}$.

\section{Statistics}

All statistical analyses were performed using GraphPad Prism (version 5 for Windows; GraphPad Software, San Diego, Calif., USA; www.graphpad.com). Because most of the data had a skewed distribution, nonparametric tests for the statistical analysis were used. To determine differences between cattle breeds, the KruskalWallis test was used, followed by Dunn's multiple posttest to compare paired differences in the sum of ranks. For this analysis, all breeds with 1-4 individuals were pooled into one group, i.e. 'other breeds'. The Mann-Whitney U test was used to determine differences between genders. Spearman correlations were used to assess relationships between parameters. $\mathrm{p}<0.05$ was considered statistically significant.

Allergen Levels in the Hair of Different Cattle Breeds

\section{Results}

Overall, a wide variability in protein and allergen levels was observed between individual samples of all breeds $(\mathrm{n}=80)$. The protein content differed by about 35 -fold (345-11,966 $\mu \mathrm{g} / \mathrm{g}$, median 2,962 $\mu \mathrm{g} / \mathrm{g}$ ), the bovine hair allergen content differed by about 500-fold (37-18,553 $\mu \mathrm{g} / \mathrm{g}$, median $2,448 \mu \mathrm{g} / \mathrm{g})$, and the Bos $\mathrm{d} 2$ content differed by about 1,200 -fold $(5.3-6,323 \mu \mathrm{g} / \mathrm{g}$, median $677 \mu \mathrm{g} / \mathrm{g})$. To investigate the Bos $\mathrm{d} 2$ proportion of cow hair allergen content, the reactivity of calibration standards of both ELISAs was examined in a 'cross-assay' design. This comparison resulted in parallel dose-response curves in both assays. The cow dander standard contained $36 \%$ Bos $\mathrm{d} 2$. Similar values were obtained through the calculation of Bos $\mathrm{d}$ 2/bovine hair allergen ratios. The median value was 0.28 , ranging from $0.06-0.59$.

Large quantitative variations also existed among individual animals of the same breed. The highest variability occurred within Simmental cattle $(n=31)$, with a 600 -fold difference in Bos $\mathrm{d} 2$ concentration. The results, sorted by 
Fig. 1. Protein concentration $(\mathbf{a}, \mathbf{b})$, bovine hair allergen levels (c, d), Bos d 2 levels (e, f), and Bos d 2/bovine hair allergen ratio (g, h) in cattle hair extracts sorted by breed (a, $\mathbf{c}, \mathbf{e}, \mathbf{g})$ and gender $(\mathbf{b}, \mathbf{d}, \mathbf{f}, \mathbf{h})$. Lines represent medians. ${ }^{* * *} \mathrm{p}<0.001$.

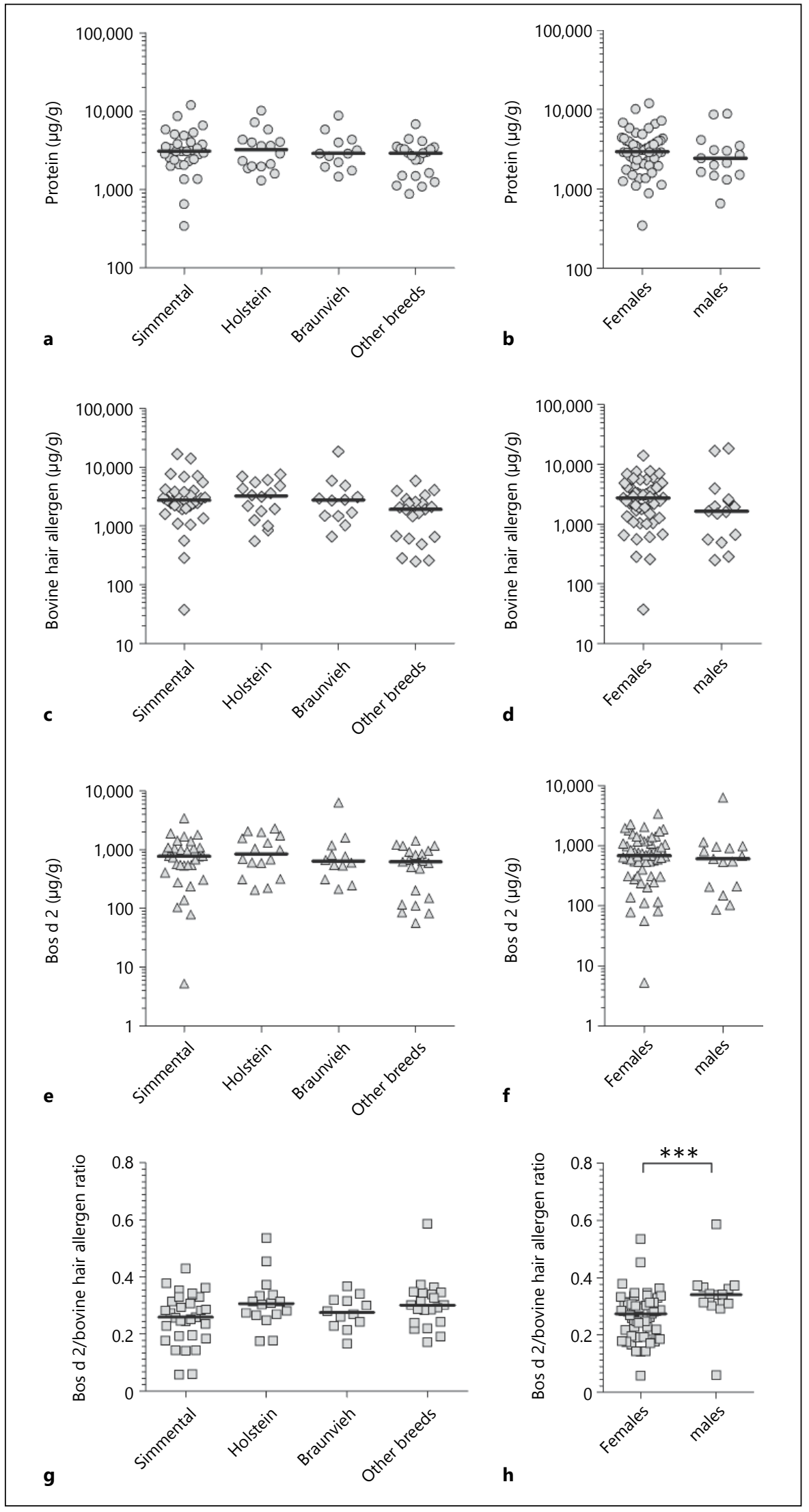




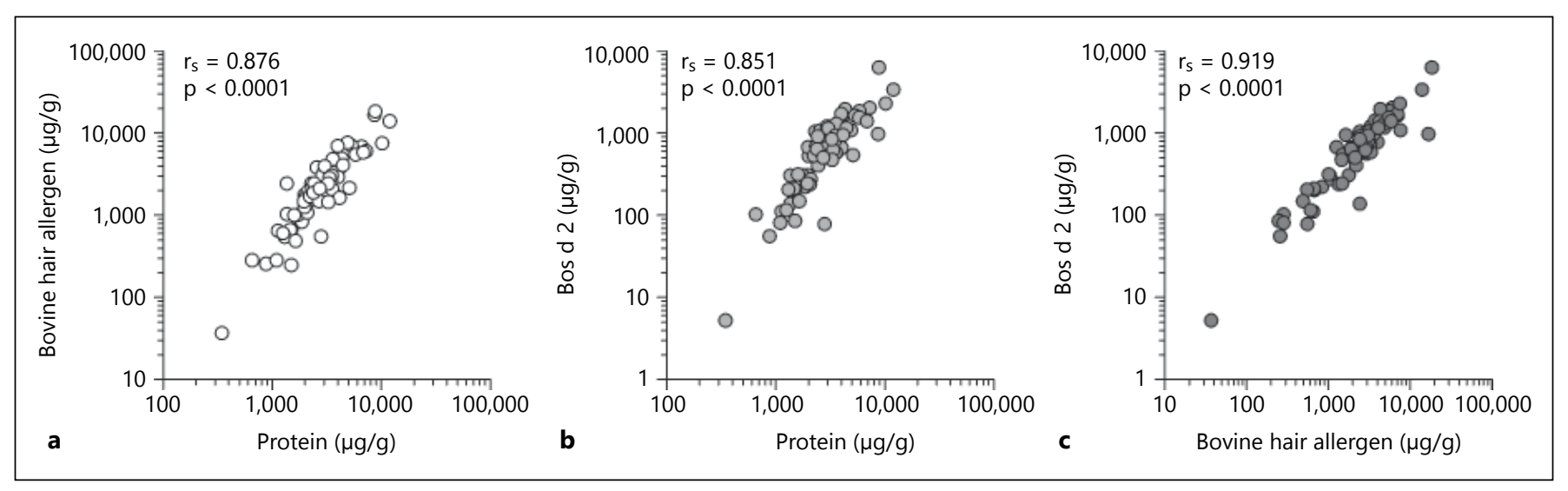

Fig. 2. Correlations between different quantification methods. a Protein vs. bovine hair allergen. b Protein vs. Bos d 2. c Bovine hair allergen vs. Bos d 2. $\mathrm{r}_{\mathrm{S}}=$ Spearman's rank correlation coefficient.

breed and gender, are presented in table 1 and figure 1 . When classified according to breed, the lowest bovine hair allergen and Bos $\mathrm{d} 2$ levels were found in the hair of Angus and Angler cattle, and the highest levels were detected in the hair of Murboden and Tux-Zillertal cattle. However, these breeds were represented only by 1 or 2 animals. Because of the limited sample size for the majority of breeds, the statistical analysis was firstly performed for the 3 most common breeds. No statistically significant differences were found between Simmental, Holstein, and Braunvieh cattle using the nonparametric Kruskal-Wallis test for all tested parameters $(\mathrm{p}=0.97$ for protein, $\mathrm{p}=0.87$ for bovine hair allergen, $\mathrm{p}=0.60$ for Bos $\mathrm{d} 2$, and $\mathrm{p}=0.26$ for the Bos d 2 /bovine hair allergen ratio). When the other-breeds group was included in the analysis, there were also no significant differences. For example, the median Bos d 2 concentration was $770 \mu \mathrm{g} / \mathrm{g}$ for Simmental, $842 \mu \mathrm{g} / \mathrm{g}$ for Holstein, $635 \mu \mathrm{g} / \mathrm{g}$ for Braunvieh, and $625 \mu \mathrm{g} / \mathrm{g}$ for 'other breeds. The Bos $\mathrm{d} 2 /$ bovine hair allergen ratio was also very consistent among the 4 groups, ranging from 0.26 to 0.30 . Regardless of the breed, there were no differences in protein or Bos d 2 levels between male and female animals. A slight but nonsignificant difference $(\mathrm{p}=0.09)$ was observed in bovine hair allergen content (males $1,640 \mu \mathrm{g} / \mathrm{g}$ vs. females $2,747 \mu \mathrm{g} / \mathrm{g}$ ). Statistical significance was, however, observed for the Bos $\mathrm{d} 2$ /bovine hair allergen ratio, which was significantly higher in males than in females ( 0.34 vs. 0.27 ; $\mathrm{p}=0.0005)$. This analysis was not possible within the breeds because of the small number of male animals in each group.

Protein, bovine hair allergen, and Bos $\mathrm{d} 2$ levels were strongly and significantly correlated (fig. 2), with the best correlation observed between bovine hair allergen and Bos $\mathrm{d} 2$ values $\left(\mathrm{r}_{\mathrm{S}}=0.92, \mathrm{p}<0.0001\right)$.

Allergen Levels in the Hair of Different Cattle Breeds

\section{Discussion}

The analysis of 80 hair samples from 16 different cattle breeds led to the finding of considerable quantitative differences in protein and allergen content among individual animals, but without any clear association to a particular breed or gender. As the sample numbers for 13 breeds were small (limited to mostly 1 or 2 individuals per breed), the statistical analysis was performed for the 3 most abundant cattle breeds: Holstein, Simmental, and Braunvieh. No statistical differences in protein, allergen, or Bos $\mathrm{d} 2$ content were found among these breeds. In addition, the other 13 breeds, as a group, showed a similar distribution, range, and median compared to the 3 most abundant breeds and also did not differ significantly. Nevertheless, differences in allergen content cannot be excluded for the breeds with low sample numbers.

The collected samples are quite representative of the frequency of cattle breeds in Germany. According to the Federal Statistical Office, there are about 12.7 million cattle in Germany (50\% dairy cattle, 39\% dual purpose cattle, and $11 \%$ beef cattle) [13]. Simmental and Braunvieh are the most prevalent dual-purpose breeds, whereas Holstein (Holstein-Friesian including Red Holstein) is the most common breed reared for dairy production, even worldwide. The 3 breeds together account for nearly $80 \%$ (48\% Holstein, 28\% Simmental, and 3.4\% Braunvieh) of the entire cattle livestock in Germany. Other breeds are less frequently raised and the livestock populations are small. For example, the number of breeds raised for beef consumption, such as Limousin, Charolais, and Angus, averages about $1.6,1.1$, and $0.7 \%$ of the total German cattle, respectively. Some breeds, such as Murnau-Werden-

Int Arch Allergy Immunol 2015;167:9-15 
fels or Murboden, are extremely rare (a few hundred animals) and are often included in government conservation programs because of their danger of extinction. Therefore, our study covers the most important breeds with regard to their allergological relevance for the majority of cattle farmers.

High inter- and within-breed variations in Bos $\mathrm{d} 2$ levels have been previously reported [12]. In their study, Heutelbeck et al. [12] described 60-fold differences in Bos d 2 content in individual hair samples between breeds ( $\mathrm{n}=18$ ) and up to 30 -fold differences within the same breed (the number of tested samples was between 2 and 4). In our study, Bos d 2 concentrations differed by even more than 1,000-fold between individual samples $(\mathrm{n}=$ 80 ) and by about 600 -fold within Simmental cattle ( $\mathrm{n}=$ 31 ). These results indicate that individual factors strongly influence allergen production and some animals might be classified as either high or low allergen producers within the same breed. It is striking that our Bos $\mathrm{d} 2$ results for several breeds are on average higher than the Bos $\mathrm{d} 2 \mathrm{lev}$ els reported by Heutelbeck et al. [12] (e.g. median 842 vs. $101 \mu \mathrm{g} / \mathrm{g}$ for Holstein or $635 \mathrm{vs.} 142 \mu \mathrm{g} / \mathrm{g}$ for Braunvieh), although assays with the same monoclonal antibodies were used. These differences may be related to the different extraction methods. Hair samples were rotated for $1 \mathrm{~h}$ instead of $24 \mathrm{~h}$ or longer, and we used the nonionic detergent Tween 20 in the extraction buffer, which is useful for cell lysis and protein solubilization and recommended for the optimization of allergen extraction [14]. The different assay conditions (e.g. antibody concentrations, standard, and conjugate) can influence the results as well.

A high variability in major allergen levels was also reported for dogs. Can $\mathrm{f} 1$ levels varied by even up to 4 orders of magnitude among dogs of the same breed $[15,16]$. However, in contrast to our results, Can $\mathrm{f} 1$ levels in dog hair were significantly related to the breed, e.g. poodles had the highest whereas Labrador retrievers had the lowest Can $\mathrm{f} 1$ levels. However, differences among dog breeds were small compared to the enormous variability within a breed, and the authors of both studies concluded that a hypoallergenic dog breed does not exist. Qualitative and quantitative differences in allergenic composition have been also studied in horses. Using immunoblotting, Felix et al. [17] determined IgE-binding profiles of dander extracts for several horse breeds. Considerable inter- and within-breed variations were observed, but no breed-specific allergen profile or allergen amount was found.

Currently, there is no data available for cattle, and contradictory results have been published for dogs and cats with respect to sex differences. Ramadour et al. [16] re- ported that male dogs had significantly higher Can $\mathrm{f} 1$ concentrations in their hair compared to female dogs, although the difference was small (11.75 vs. $8.89 \mu \mathrm{g} / \mathrm{g}, \mathrm{p}=0.037)$ [16]. No significant effect of sex on Can $f 1$ levels was seen in the study by Vredegoor et al. [15]. Two studies have shown that Fel $\mathrm{d} 1$ levels are significantly higher in skin or fur washes of male cats compared to female cats [18]. Previous experiments have also found that Fel $\mathrm{d} 1$ production is testosterone dependent [19]. However, a study by Buters et al. [20] indicated that Fel $\mathrm{d} 1$ levels in hair extracts are not significantly different between males and females, or between castrated and noncastrated cats. In our study, males had even lower levels of bovine hair allergen than females, but they had similar Bos $\mathrm{d} 2$ contents. This resulted in significantly higher Bos $\mathrm{d}$ 2/bovine hair allergen ratios in males, confirming the results of previous studies which showed that major allergen levels appeared to be higher in male animals. However, this effect was rather small (0.34 vs. 0.27 ). Nevertheless, this result suggests that quantitative differences could exist in other bovine hair allergens between genders. Currently, besides Bos $\mathrm{d} 2$ assay, no techniques to measure these allergens are available.

In our study, the results of allergen levels found in hair samples may have been partially influenced by the airborne allergen concentration in the cattle stables. As for the major allergens of other mammals, Bos $\mathrm{d} 2$ belongs to the lipocalin family of proteins, which predominantly function as carriers of pheromones and odorants $[5,21]$. In general, lipocalins tend to stick to small dust particles that can stay suspended in the air for long periods after disturbance. In stables, the levels of bovine hair allergens in airborne dust can reach immensely high values. In our previous report, the median allergen concentration was $14 \mathrm{mg} / \mathrm{g}$ dust, and allergen levels differed by about 100fold between cow stables (all with Simmental cattle), ranging from 5,000 to $560,000 \mu \mathrm{g} / \mathrm{m}^{2}$ [11]. It is likely that some proportion of the airborne allergen produced by livestock settles back onto the fur during the sedimentation process. Nevertheless, the majority of allergen measured in hair has to be derived from the animal itself. Bos d 2 has been shown to be produced in apocrine sweat glands and transported to the skin surface as a pheromone carrier [22]. The secretions of apocrine glands accumulate on hair and then spread through hair movements in the environment.

Besides the environmental conditions in stables, the method of sample collection could have influenced the results of this study. The hair was not collected from exactly the same body part for each cow. Previous studies have shown that the quantity of Fel $\mathrm{d} 1$ on cat skin and fur 
varies between different anatomical sites. Fel d 1 concentrations were higher in the neck and face region than in the chest, back, and haunch areas [23, 24]. However, this unequal distribution on fur could result from licking and grooming which is specific for cats. In contrast, Can $\mathrm{f}$ 1 concentrations have been found to be similar between different anatomical zones of dogs [16]. According to $\mathrm{Ku}-$ rosumi et al. [25], nonprimate mammals have apocrine sweat glands (producers of Bos d 2 in cattle) over the greater part of their body. Based on this fact, it is unlikely that the sampling location on the bodies of the cattle substantially influenced the results of our study.
In conclusion, our study suggests that allergen production in cattle is not breed-specific but differs by up to 3 orders of magnitude between individual animals. Furthermore, the sex of the animals seems to only marginally influence the allergen content.

\section{Acknowledgments}

We especially thank Lydia Bruckmaier from the Sozialversicherung für Landwirtschaft, Forsten und Gartenbau (SVLFG) for collection of cattle hair samples, and Jasmin Obermanns for technical assistance with hair extractions and ELISA assays.

\section{References}

1 Heutelbeck ARR, Janicke N, Hilgers R, Kütting B, Drexler H, Hallier E, Bickeböller H: German Cattle Allergy Study (CAS): public health relevance of cattle-allergic farmers. Int Arch Occup Environ Health 2007;81:201-208.

2 Prahl P: Allergens in cow hair and dander: origin of cow allergens in the environment. Allergy 1981;36:561-571.

3 Prahl P, Weeke B, Løwenstein H: Quantitative immunoelectrophoretic analysis of extract from cow hair and dander: characterization of the antigens and identification of the allergens. Allergy 1978;33:241-253.

4 Ylönen J, Mäntyjärvi R, Taivainen A, Virtanen T: Comparison of the antigenic and allergenic properties of three types of bovine epithelial material. Int Arch Allergy Immunol 1992;99:112-117.

5 Mäntyjärvi R, Parkkinen S, Rytkönen M, Pentikäinen J, Pelkonen J, Rautiainen J, Zeiler T, Virtanen T: Complementary DNA cloning of the predominant allergen of bovine dander: a new member in the lipocalin family. J Allergy Clin Immunol 1996;97:1297-1303.

6 Rautiainen J, Auriola S, Rouvinen J, Kauppinen J, Zeiler T, Novikov D, Virtanen T, Mäntyjärvi R: Molecular and crystal properties of Bos d 2, an allergenic protein of the lipocalin family. Biochem Biophys Res Commun 1998; 247:746-750.

7 Ylönen J, Mäntyjärvi R, Taivainen A, Virtanen T: IgG and IgE antibody responses to cow dander and urine in farmers with cowinduced asthma. Clin Exp Allergy 1992;22: 83-90.

8 Mattsson L, Lundgren T, Olsson P, Sundberg M, Lidholm J: Molecular and immunological characterization of Can $\mathrm{f} 4$ : a dog dander allergen cross-reactive with a $23 \mathrm{kDa}$ odorantbinding protein in cow dander. Clin Exp Allergy 2010;40:1276-1287.

9 Rautiainen J, Rytkönen M, Parkkinen S, Pentikäinen J, Linnala-Kankkunen A, Virtanen
T, Pelkonen J, Mäntyjärvi R: cDNA cloning and protein analysis of a bovine dermal allergen with homology to psoriasin. J Invest Dermatol 1995; 105:660-663.

10 Hochwallner H, Schulmeister U, Swoboda I, Spitzauer S, Valenta R: Cow's milk allergy: from allergens to new forms of diagnosis, therapy and prevention. Methods 2014;66:22-33.

11 Zahradnik E, Sander I, Bruckmaier L, Flagge A, Fleischer C, Schierl R, Nowak D, Sültz J, Spickenheuer A, Noss I, Brüning T, RaulfHeimsoth M: Development of a sandwich ELISA to measure exposure to occupational cow hair allergens. Int Arch Allergy Immunol 2011;155:225-233.

12 Heutelbeck ARR, Junghans C, Esselmann H, Hallier E, Schulz TG: Exposure to allergens of different cattle breeds and their relevance in occupational allergy. Int Arch Occup Environ Health 2009;82:1123-1131.

13 Statistisches Bundesamt: Land- und Forstwirtschaft, Fischerei: Viehbestand. 2014. https://www.destatis.de/DE/Publikationen/ Thematisch/LandForstwirtschaft/ ViehbestandTierischeErzeugung/Viehbes tand2030410145314.pdf?__blob=publication File.

14 Raulf M, Buters J, Chapman M, Cecchi L, Blay F de, Doekes G, Eduard W et al: Monitoring of occupational and environmental aeroallergens - EAACI position paper: concerted action of the EAACI IG Occupational Allergy and Aerobiology \& Air Pollution. Allergy 2014;69:1280-1299.

15 Vredegoor DW, Willemse T, Chapman MD, Heederik DJ, Krop EJ: Can $\mathrm{f} 1$ levels in hair and homes of different dog breeds: lack of evidence to describe any dog breed as hypoallergenic. J Allergy Clin Immunol 2012;130:904-909.e7.

16 Ramadour M, Guetat M, Guetat J, El Biaze M, Magnan A, Vervloet D: Dog factor differences in Can $\mathrm{f} 1$ allergen production. Allergy 2005; 60:1060-1064.
17 Felix K, Ferrándiz R, Einarsson R, Dreborg S: Allergens of horse dander: comparison among breeds and individual animals by immunoblotting. J Allergy Clin Immunol 1996; 98:169-171.

18 Jalil-Colome J, de Andrade AD, Birnbaum J, Casanova D, Mège JL, Lanteaume A, Charpin D, Vervolet D: Sex difference in Fel d 1 allergen production. J Allergy Clin Immunol 1996; 98:165-168.

19 Zielonka TM, Charpin D, Berbis P, Luciani P, Casanova D, Vervloet D: Effects of castration and testosterone on Fel d I production by sebaceous glands of male cats. 1. Immunological assessment. Clin Exp Allergy 1994;24: 1169-1173.

20 Buters J, Weichenmeier I, Weingart C, Pusch G, Brunnberg L, Schmidt-Weber C: 'Kill' the wrong cat? EAACI-WAO World Allergy Asthma Congr, Milan, 2013.

21 Virtanen T, Zeiler T, Mäntyjärvi R: Important animal allergens are lipocalin proteins: why are they allergenic? Int Arch Allergy Immunol 1999;120:247-258.

22 Rautiainen J, Rytkönen M, Syrjänen K, Pentikäinen J, Zeiler T, Virtanen T, Mäntyjärvi R: Tissue localization of bovine dander allergen Bos d 2. J Allergy Clin Immunol 1998;101: 349-353.

23 Avner DB, Perzanowski MS, Platts-Mills TA, Woodfolk JA: Evaluation of different techniques for washing cats: quantitation of allergen removed from the cat and the effect on airborne Fel d 1. J Allergy Clin Immunol 1997; 100:307-312.

24 Carayol N, Birnbaum J, Magnan A, Ramadour M, Lanteaume A, Vervloet D, Tessier Y, Pageat P: Fel d 1 production in the cat skin varies according to anatomical sites. Allergy 2000;55:570-573.

25 Kurosumi K, Shibasaki S, Ito T: Cytology of the secretion in mammalian sweat glands. Int Rev Cytol 1984;87:253-329. 